Chapter 17

\title{
Climatic Restrictions for Maximizing Soybean Yields
}

\author{
Ana Maria Heuminski de Avila, \\ José Renato Bouças Farias, Hilton Silveira Pinto and \\ Felipe Gustavo Pilau
}

Additional information is available at the end of the chapter

http://dx.doi.org/10.5772/52177

\section{Introduction}

Soybean (Glycine max L.) is a leguminous species, native to Northeast Asia, and is one of the most important sources of oil and protein for livestock and the human diet. The crop is also being used to make diesel biofuel from the oil extracted from the seed. Today, the world's top producers of soybean are the United States (90 million ton), Brazil (68 million tons), Argentina (52 million tons), China (15 million tons) and India. These countries' production represents more than $90 \%$ of global soybean production. In the 2009/2010 harvest the world produced 261.57 million tons of soybean grain on 102.38 million hectares define this by [1]. Also, according to [1], over a period of 50 years, soybean production area increased $330 \%$, rising from 23.81 million in 1961 to the current production area.

Currently with a world population of 7.0 billion people, which is projected to increase to more than 9.0 billion by 2050 and 10 billion by 2100 [2], there is a concern to maintain food. To achieve a gradual increase in world production of soybeans, two alternatives are possible: increased production area and/or increased productivity. Because planted area has increased 37\% between 2000 to 2011 [1] and productivity has increased only $17.8 \%$, the second solution looks to be the better option

Among all the factors inherent in agricultural production, the climate are the most difficult to control and it exercises greater limiting action in the maximum yield. It worsens according to the difficult to predict occurrences of adverse weather, the main risk factors in the exploration of major crops. Stress non biotic such as drought, excessive rain, extreme temperatures and low light can significantly reduce yields of crops and restrict the locations, times and soils, where the species most important commercially, can or not be cultivated. 


\section{Agrometeorological conditioners of soybean productivity}

\subsection{Solar radiation}

In general, soybean production potential and risk is controlled by prevailing climatic conditions and genotypic performance. The basic source for crop production is solar radiation which acts as an energy source for photosynthesis. Light quality also acts to influence plant height and phenological development [3].

The light spectrum duration and quality besides the radiation intensity are determinants of morphological and phenotypic responses striking in soybean, such as plant height, induction of flowering and ontogeny [4]. The final yield of dry matter from the plant depends on the solar radiation absorbed by the leaves and the efficiency with which these convert radiant energy into chemical energy through photosynthesis.

Soybean is a qualitative short-day plant and must receive a certain day length or less so that developmental timing is optimal for the location [5]. This means that adaptability of each cultivar varies with latitude [6]. Movement of soybean to the central and northern regions of the country from the original southern region has faced the challenge of adaptation to shorter day lengths occurring in these regions (from Tropic of Capricorn to Equator Line). To deal with this challenge Brazilian agricultural scientists have sought to introduce the 'long juvenile period'. This characteristic gives soybean a longer developmental period under short days so that it can accrue enough dry matter for optimal yield [7].

Each variety has its critical photoperiod above which flowering is delayed. Flowering occurs anyway, but more rapidly as the days become shorter. It slows progressively, as the photoperiod exceeds the critical period for each genotype.

\subsection{Temperature}

In addition to photoperiod, temperature also influences growth and developmental timing in soybean. This occurs due to the effect of temperature on the rate of metabolic reactions, the diffusion rate of gases through aqueous media and the solubility of nutrients in the plant. Soybean grows best at temperatures between $20^{\circ} \mathrm{C}$ and $30^{\circ} \mathrm{C}$. Greatest number of pods per plant is obtained under mild temperature conditions having a day/night temperature combination of $26 / 14^{\circ} \mathrm{C}$ [8]. Temperatures above $40^{\circ} \mathrm{C}$ during the vegetative stage (emergence to first flower) reduce growth and hastens flowering. High temperatures during the reproductive phase can cause reductions in seed number and seed weight, thus reducing grain quality and yield. If the high temperature is associated with a drought, the losses on grain production are even higher [7]. On the other hand, cold regions where the temperature is equal or below to $10 \mathrm{C}$ is not properly to soybean cultivation, because in these places, the vegetative growth and the development become small or null. 


\subsection{Water availability}

Ninety $\%$ of the total soybean fresh weight (biomass) is water and water acts in all physiological and biochemical processes in the plant, working as a solvent, carrying gases, minerals and other plant solutes and acting as a thermal regulator to cool and maintain plant temperature [9].Water availability is important in three periods of soybean development: germination, emergence and flowering-grain filling. During the first period, both: excess or lack of water is detrimental to crop establishment and obtaining a good uniformity of the plant population and the surplus water more limiting than the deficit. Soybean seeds need to absorb at least $50 \%$ of its weight in water to ensure a good germination. At this stage, the water content in soil must not exceed $85 \%$ of the total maximum available, or must not be less than $50 \%$ [10]. The roots can reach over $1.5 \mathrm{~m}$ deep, however heavy and compacted soils hinder root penetration, further reducing the effective depth of the root system of soybean plants.

Another serious risk in Brazilian soybean production is drought stress. The problem is more pronounced in tropical and subtropical, semiarid and arid climates where up to $8 \mathrm{~mm} /$ day may be lost by evapotranspiration.

The necessity of water needs by soybean gradually increase with plant development, peaking at 7 to $8 \mathrm{~mm}$ /day during flowering through grain filling [11]. The negative effect of water deficiency on yield depends on the phenological stage in which soybean is affected by drought stress. For example, if drought occurs during the germination and emergence stages, plant stand is reduced. In the flowering period it can cause flower abortion and prevents anthesis while in the grain filling stage drought affects seed weight [12]. The lack of water induces these effects through reducing the efficiency of the photosynthesis [13].

An abundance of water is also harmful to yield by causing water logging of the soil. A very wet soil results in low aeration which reduces root growth, can cause nutritional deficiency and promotes the attack of root diseases.

\section{General issues}

The climate exerts the greatest limiting effect on yield. Thus, proper management of the soybean crop depends on climate information at the site of interest. Agroclimatic zoning is used to provide climate data to the agricultural community [14].

Cardoso et al. [15] verified that in general the precipitation climate forecasts contribution to the improvement of estimated soybean productivity, primarily in periods when the crop is more sensitive to water deficit. The improvement of estimated soybean productivity may give a contribution to agribusiness sector, in order to turn more realistic expectations available and assist on the strategic planning for the decisions maker.

Knowledge of favorable periods for soybean culture, such as timing of the rainy season and duration of intermittent dry wet spells is very important for planning various agronomic operations such as preparing a seedbed, proper maturity, sowing, weeding, harvesting, 
threshing and drying. This minimizes crop risk and optimizes use of resources such as water, labor, fertilizer, herbicides and insecticides. Knowledge of the critical periods for crop development in conjunction with knowledge of climatic factors is very helpful for adjusting management practices for best crop yield and quality.

As already highlighted climate stresses such as drought, excessive rain, extreme temperatures and low irradiance can significantly reduce yields of crops and restrict areas and timings of production. The most important factors useful to know for soybean production are air temperature, photoperiod and water supply [10].

In Brazil, a system has been developed for identification of suitable areas for planting soybean. The Agricultural Zoning Program has been coordinated by the Ministry of Agriculture and EMBRAPA since 1996. This program has the objective of defining planting seasons guarantee at least an $80 \%$ probability of having an adequate water supply for the growing season. The planting periods were defined through the simulation of a climatic water balance that gives an index of water supply called by the Portuguese initials as ISNA (Water Necessity Satisfaction Index) using historical rainfall data, potential evapotranspiration, physiological characteristics of each crop and water retention by the soil [16].

\section{Climate change: A challenging}

Since 1988, agricultural scientists have been studying climate change mainly according to the rules of IPCC (Intergovernmental Panel on Climate Change). In recent years global studies have shown consistent changes in air temperature and rainfall in many places of the world [17, 18]. The Earth's average temperature can rise between $1.8^{\circ} \mathrm{C}$ and $4.0^{\circ} \mathrm{C}$ in the next 100 years [19] with more significant increases for minimum than maximum air temperature. However, in the case of South America temperature trends may not be consistent [20]. Contemporary scientific studies have warned of anomalies in temperature and precipitation patterns indicating the occurrence of global change, with direct consequences on human activities, especially those related to agricultural production [18].

Globally, agriculture accounts for $23 \%$ of all emissions of greenhouse gases (GHG) that come from human activity. Parts of these (15\%) are derived from agricultural practices and the other part (8\%) is from changes in land use [21]. However, in Brazil a greater proportion of agriculture's contribution to GHG comes from agricultural practices [22]. Soil is also an important source of carbon emission and sequestration [23]. Soil management practices affect to what degree these processes go on. Conventional tillage operations tend to increase carbon release to the atmosphere, whereas conservation tillage and crop rotation with their increased contribution of crop organic matter to the soil tend to increase carbon sequestration [24]. These practices also improve the physical, chemical, and biological balances in the soil. Current agriculture through its production of fiber, bioenergy and food reduces pollution and mitigates GHG emissions [25].

A good example are the results of a research carried out at Embrapa Soja (Londrina, PR, Brazil) for levels of Carbon (C) and Nitrogen (N) in soil under no-tillage (NT) and conventional sowing 
(CT). [26] found that the biggest difference in results between NT and CT systems occurs in the first $30 \mathrm{~cm}$ of the soil profile with a $29 \%$ increase in total C content of soil in NT vs. CT. Still, disputing claims of U.S. researchers [27], the survey confirmed significant increases in carbon sequestration in the $0-60 \mathrm{~cm}$ soil layer. They determined that in NT vs. CT there was $18 \%$ and $16 \%$ increase in the $\mathrm{C}$ and $\mathrm{N}$ contents, respectively, of the soil organic matter. Within the same $0-60 \mathrm{~cm}$ profile, $\mathrm{C}$ and $\mathrm{N}$ content of the microbial mass increased $35 \%$ and $23 \%$, respectively. Over the 20 years of the research, $C$ and $N$ rates of accumulation within the $0-60 \mathrm{~cm}$ layer of soil were $800 \mathrm{~kg} \mathrm{C} \mathrm{ha}^{-1}$ year $^{-1}$ and $70 \mathrm{~kg} \mathrm{~N} \mathrm{ha}^{-1}$ year-1, respectively, in NT vs. CT. According to the Agricultural Census [28], in 2006 the total no-tillage area for crops in Brazil was 15.6 million hectares.

Because of the rising temperatures associated with global warming, the adaptability of certain crops to an area may change. In particular, drought problems may become worse and yield potential reduced. Because of this, agricultural scientists have been developing strategies to avoid potential adverse climatic changes, especially those related to drought stress.

Problems with drought and temperature stress have to be resolved with research for adaptation like developing new soybean genotypes and cultivars with heat and water loss tolerance.

In Brazil, the southeast region, which accounts for $40 \%$ of soybean production, has suffered severe losses due to the occurrence of droughts. Growing seasons in the years 2003 and 2004 for example, showed yield losses due to drought close to $24 \%$ and $44 \%$, respectively. In 2004/05 growing season, Rio Grande do Sul state alone, lost an average $70 \%$ of its production. In the last 10 seasons, the direct losses can be estimated by more than $\$ 18$ billion due to the occurrence of drought [29].

The search for commercial cultivars more drought tolerant through classical breeding are relatively difficult because of the complex mechanisms developed by plants to ameliorate this stress. Biotechnology is also an important ally in the breeding for drought tolerant cultivars. With the sequencing of the soybean genome it becomes possible to understand the function of a specific gene and how it interacts with other genes. This allows for breeding new cultivars with greater resistance to environmental stresses.

\section{Final considerations}

Currently inside the world agriculture, the increases of yields and the reduces of the costs and risks from failure, have become the basic requirements of competitive. Besides, in terms of economic activity with narrow profit margins, there is no room for risk.

Immense progress has been achieved, adapting the soybeans to obtain high levels of incomes in areas of lower latitudes. The photoperiod limitation was eliminated by the careful selection and also the development of the germoplasma less sensitive to photoperiod. The yields are extremely dependent of the water available and probably are also necessary to increase it to meet the crop transpiration and the productivity enhancement. 
Environmental forecasts signaling the increase of the temperatures in the upcoming decades which mean the climate change. The difficulty to feed the world population, (which is in growing fast) using only traditional technologies will be immense shortly. The development of variety tolerant to adverse climatic conditions such as drought and high temperatures, it will be essential, as well as the development of new research tools in the areas of plant biotechnology and ecophysiology. It will enable us to understand the details of the processes involved in physiological and agronomic crops. Only with the development and continued growing in agricultural research, you can ensure food quality and quantity for future generations.

\section{Author details}

Ana Maria Heuminski de Avila ${ }^{1}$, José Renato Bouças Farias², Hilton Silveira Pinto ${ }^{3}$ and Felipe Gustavo Pilau ${ }^{4}$

1 CEPAGRI, UNICAMP, Campinas - SP, Brasil

2 CNPSO, EMBRAPA, Londrina - PR, Brasil

3 IB and CEPAGRI, UNICAMP, Campinas - SP, Brasil

4 Departamento de Fitotecnia, CCR, UFSM, Santa Maria - RS, Brasil

\section{References}

[1] FAOSTAT (2012). Food and Agriculture Organization of the United Nations. FAOSTAT. www.faostat.org (accessed 27 June 2012).

[2] UN (2012). United Nations Department of Economic and Social Affairs. Population Division. http://www.un.org/esa/population/unpop.htm. (accessed 19 June 2012.

[3] Chang, J.H., 1974: Climate and Agriculture: An Ecological Survey. Chicago, Aldine Publishing Company.

[4] Thomas, JF (1994). Ontogenetic and morphological plasticity in crop plants. In: BOOTE, KJ et al (comp.) Physiology and determinations of crop yield. Madison: ASA/ CSSA/SSSA, cap. 7B, p.181-185.

[5] Garner, WW; Allard, H A (1920). Effect of the relative length of day and night and other factors of the environment on growth and reproduction in plants. Journal of $A g$ ricultural Research, Washington, DC, v. 48, n. 7, p. 553-606. 
[6] Mavi HS and Tupper GT (2004). Agrometeorology: principles and applications of climate studies in agriculture, The Haworth Press, Inc., New York, 364 p.

[7] Farias, JRB; Nepomuceno, AL; Neumaier, N (2007). Ecofisiologia da soja. Londrina: Embrapa Soja, 2007. 9p. (Embrapa Soja. Circular técnica, 48).

[8] Thomas, JF and CD Raper, Jr. (1981). Day and night temperatures during early reproductive development of soybeans: Influence on carpel initiation and growth. Bot. Gaz. 142:183-187

[9] Farias, JRB; Neumaier, N; Nepomuceno, AL (2009). Soja. In: Monteiro, J. E. B. A. (Org.). Agrometeorologia dos cultivos: o fator meteorológico na produção agrícola. Brasília: INMET, 2009. p. 263-277.

[10] EMBRAPA (2008). Tecnologias de produção de soja: região central do Brasil, 2008. Londrina, 2008. 280p. (Sistemas de produção/ Embrapa Soja, n. 12).

[11] Berlato, Moacir A (1981). Bioclimatologia da soja. In: Miyasaka, S.; Medina, J.C. ed. A soja no Brasil. Campinas:ITAL. p.175_184.

[12] Fageria, NK (1989). Solos tropicais e aspectos fisiológicos das culturas. Brasília : EmbrapaDPU, 1989. 425p. (Embrapa-CNPAF. Documentos, 18).

[13] Miyasaka, S, Medina, JC (1981). A soja no Brasil. 1ª ed., 479p.

[14] Sentelhas, PC; Monteiro, JEB de A (2009). Agrometeorologia dos Cultivos: Informações para uma Agricultura Sustentável. In: Monteiro, J. E. B. A. (Org.). Agrometeorologia dos cultivos: o fator meteorológico na produção agrícola. Brasília: INMET, p. 3-12.

[15] Cardoso, AO; Avila, AMH; Pinto, HS. Assad, E(2011). Use of Climate Forecasts to Soybean Yield Estimates, Soybean Physiology and Biochemistry, Hany A. El-Shemy (Ed.), ISBN: 978-953-307-534-1, InTech, Available from: http://www.intechopen.com/ books/soybean-physiology-and-biochemistry/use-of-climate-forecasts-to-soybeanyield-estimates

[16] Farias, JRB; Assad, ED; Almeida, IR; Evangelista, BA; Lazzarotto, C; Neumaier, N; Nepomuceno, A.L (2001). Caracterização de risco de déficit hídrico nas regiões produtoras de soja do Brasil. Revista Brasileira de Agrometeorologia, 9, 415-421.

[17] Alexander, LV; Zhang, X; Peterson, TC; Caesar, J; Gleason, B; Tank, AMK.; Haylock, M; Collins, D; Trewin, B; Rahimzadeh, F; Tagipour, A; Kumar, KR; Revadekar, J; Griffiths, G; Vincet, L; Stephenson, DB; Burn, J; Aguilar, E; Brunet, M; Taylor, M; New, M; Zhai, P; Rusticucci, M; Vazquez-Aguirre, JL(2006). Global observed changes in daily climate extremes of temperature and precipitation. Journal of Geophysical Research, Washington, v. 111, DO 5109, doi: 10.1029/2005 JD006290.

[18] IPCC Assessment Report, 4., (2007). Valencia, Spain. Climate change 2007: the physical science basis: summary for policymakers. [Genebra]: IPCC, 2007b. 18 p. A report of 
Working Group I of the Intergovernmental Panel on Climate Change. http:// www.ipcc.ch (accessed March 2012).

[19] Solomon, S; Qin, D; Manning, M; Alley, RB; Berntsen, T; BIndoff, NL; Chen, Z; Chidthaisong, A; Gregory, JM; Hegerl, GC; Heimann, M; Hewitson, B; Hoskins, BJ; Joos, F; JouzeL, J; Kattsov, V; Lohmann, U; Matsuno, T; Molina, M; Nicholls, N; Overpeck, J; Raga, G; Ramaswamy, V; Ren, J; Rusticucci, M; Somerville, R; Stocker, TF; Whetton, P; Wood, RA; Wratt, D Technical summary. In: IPCC Assessment Report, 4., 2007, Valencia, Spain. Climate change 2007: the physical science basis. [Genebra]: IPCC, 2007. 74 p. A report accepted by Working Group I of the Intergovernmental Panel on Climate Change but not approved in detail. http://www.ipcc.ch/pdf/assessment-report/ar4/wg1/ar4-wg1-ts.pdf (accessed March 2012)

[20] Vincent, LA; Peterson, TC; Barros, VR; Marino, MB; Rusticucci, M; Carrasco, G; Ramirez, E; Alves, LM; Ambrizzi, T; Berlato, MA; Grimm, AM; MArengo, JA; Molion, L Moncunill, DF; Rebello, E; Anunciação, YMT; Quintana, J; Santos, JL; Baez, J; Coronel, G; Garcia, J; Trebejo, I; Bidegain M; Haylock, MR; Karoly, D (2005) Observed trends in indices of daily temperature extreme in South America 1960-2000. Journal of Climate, Washington, v. 18, p. 5011-5023, 2005.

[21] Lal, R; Logan, TJ (1995). Agricultural activities and greenhouse gas emissions from soils of the tropics. In: LAL, R.; KIMBLE, J.M.; LEVINE, E.; STEWART, B.A. (Ed.). Soil management greenhouse effect. Boca Raton: CRC Press, 1995. p.293-307.

[22] Lima, MA de (2006). Estimativa de emissões de gases de efeito estufa provenientes da queima da cana-de-açúcar no estado de São Paulo no período de 1986 a 2008 / Magda Aparecida Lima, Marcos Antonio Vieira Ligo, Elton César de Carvalho, Maria Conceição Peres Young Pessoa. - Jaguariúna: Embrapa Meio Ambiente, 2010. 23 p. : il. - (Embrapa Meio Ambiente. Documentos; 83).

[23] Bayer, C and Mielniczuk, J (1997). Características químicas do solo afetadas por métodos de preparo e sistemas de cultura. R. Bras. Ci. Solo, V. 21, p.105-112.

[24] Ciotta, MN; Bayer, C; Ernani, PR; Fontoura, SMV (2004). Albuquerque, JA; Wobeto, C Acidificação de um Latossolo sob semeadura direta. Revista Brasileira de Ciência do Solo, v.26, p.1055-1064.

[25] Costa, FS; Albuquerque, JA; Bayer, C; Fontoura, SMV; Wobeto, C (2003) Propriedades físicas de um Latossolo Bruno afetadas pelos sistemas de semeadura direta e preparo convencional. Revista Brasileira de Ciência do Solo, v. 27, p.527-535.

[26] Babujia, LC; Hungria, M; Franchini, JC; Brookes, PC (2010). Microbial biomass and activity at various soil depths in a Brazilian oxisol after two decades of no-tillage and conventional tillage. Soil Biology \& Biochemistry, v. 42, p. 2174-2181.

[27] Baker, JM; Ochsner, TE; Venterea, RT; Griffs, TJ (2007). Tillage and soil carbon sequestration - What do we really know? Agriculture, Ecosystems and Environment, v. 118, p. 1-5. doi: 10.1016/j.agee.2006.05.014 
[28] IBGE (2011). Instituto Brasileiro De Geografia e Estatística. Senso 2010. Disponível em: www.ibge.gov.br. Acesso em: agosto de 2011.

[29] Farias, JRB; Nepomuceno, AL; Neumaier, N; Tobita, S; Almeida, IR de. (2006). Restrições de disponibilidade hídrica à obtenção de elevados rendimentos de grãos de soja. In: Congresso Brasileiro de Soja, n.4., 2006, Londrina. Resumos. Londrina: Embrapa Soja, p. 32-33. 
